\title{
December

\section{Open Source for Seeds and Genetic Sequence Data: Practical experience and future strategies}

Sélim LOUAFI - Ida WESTPHAL - Maywa MONTENEGRO - Daniele MANZELLA Gloria OTIENO - SOphie STEIGERWALD - Jack KLOPPENBURG

Application of the open source concept to seeds has a promising future. It reverses the logic of the intellectual property system with a renewable stock of open source material kept outside the exclusive intellectual property realm. Legal defensibility may currently be uncertain, but as open source builds a critical mass of practitioners and supporters, wider social legitimacy could strengthen the legal power. Future extension to other subject matter and settings is discussed on the basis of lessons learnt from current open source seed implementation experience in the US, Europe and Africa.
$\mathrm{P}$ lant breeding research incentives are driven by a combination of two forms of intellectual property rights-plant variety protection and patents. Both instruments, however, generate economic, environmental and ethical friction in the seed sector for various reasons. The quest for alternative practices and non-proprietary innovation pathways is a constant concern.

Application of the open source concept to seeds is an emerging alternative. This concept-inspired from the free and open software movement-favors a no restrictions-onuse regime that is applied by an ever-growing community through a chain of bilateral commitments. Open source could overcome dysfunctions of the intellectual property regime and address some current challenges in the seed sector. These include erosion of genetic diversity, research and development lock-ins, destabilization of rural livelihoods dependent on seed renewal, and the ongoing economic concentration in the seed and chemical industries.

Nascent open source seed initiatives (see box p. 3) address the need to restore protected commons principles and practices. An open source for seeds is a legal or ethical commitment to maintain the freedom to use the seeds and any derivatives. This approach is distinct from the public domain, whereby anyone has free and open access to the seeds, with the inevitable risk of free appropriation. Conversely, the open source approach is based on viral effects (i.e. the same conditions apply for any subsequent use) and non-proprietary assets: it reverses the intellectual property rights rationale by introducing negotiated terms of access and use with the aim of keeping seeds in a protected commons. From a social standpoint, these commons are populated by community members who are willing to share freely, while excluding those who are not. Biologically, it creates a putative pool of crop varieties and associated germplasm with limitless potential for breeding, sharing and re-sharing as long as the commons protocols are upheld.

With current technological innovations, new challenges are arising as seed information is increasingly exchanged without the biological material itself. This dematerialization is a mounting concern for local communities who have long experienced appropriation of genetic resources without recompense while relying on access and benefit-sharing regimes to contest unilateral appropriation. Open source experience drawn from the software industry might also benefit seed bioinformatics in this respect.

This Perspective builds on the findings of the Open Source for Seeds (OSS) and Digital Sequence Information: Practical Experiences with OSS Implementation workshop [2017, CIRAD, Montpellier, France). It presents the open source seed principles based on practical experience from three opensource cases in the United States, Germany and East Africa. It discusses practical challenges in expanding open source to other types of subject matter and settings. 
Open source pledge versus license: two implementation strategies for open source for seeds

Two projects (see box p. 3) - the Open Source Seed Initiative [United States) and OpenSourceSeeds (Germany)-have implemented the open source approach to seeds. The first project offers access to seeds through a moral-economy pledge and the second one via a license.

The pledge is a short simple statement of ethical commitment while the license is longer and contains technical language to ensure its legal robustness. Both give people acquiring the seeds the right to freely use them, provided that they do not subsequently restrict others from access to the seeds or their derivatives [so-called copyleft clause) and exclusive rights cannot be applied at any time to the seeds.

However, rights over seeds are only possible for newly developed seeds (i.e that include a breeding investment of the rights holder]. Therefore, under the license and pledge, breeders must guarantee that they are in a position to put the 'novel' varieties under open source protection.

Both solutions have already proven to be interesting for freelance breeders, private seed savers, genebanks, and publicly funded breeders and researchers - who must increasingly make the results of their work accessible. Some legal challenges remain though, especially regarding enforcement and the absence of judicial precedent. Questions arise regarding enforcement mechanisms since the share-alike commitment in both the pledge and license only bind the two contracting parties and not third parties. More experiments with open source for seeds will be required to overcome the current legal uncertainties.

Independently of these legal issues, two social factors account for the success of these initiatives. First, open source for seeds acknowledges the incremental nature of the innovation process. Innovation trajectories can locally be focused on a wider array of crops, crop varieties and traits than the formal protection system allows, hence fulfilling a wider range of agronomic, dietary, ecological and economic needs. Second, it recognizes the primacy of communitybased governance. The protected commons is principally defined by the participants, including breeders, farmers and seed companies (but farmers are still free to save their open source seeds].

Looking ahead, we consider that open source for seeds is a viable alternative as the associated legal and legitimacy aspects are intertwined. The success of this mechanism will also depend on the possibility of extending open source for seeds to different crops, biological and digital materials, as well as to different contexts. These possible future applications are discussed in the next section.

\section{Possible future applications: crops, material and areas for which an open source pledge or license could be relevant}

Open source for what biological materials? Open source systems face the challenge of protecting some types of biological materials that are highly vulnerable to misappropriation, including landraces, indigenous varieties and crop populations. Lack of novelty in landraces is an impediment, as novelty is inherent to eligibility within existing open source seed frameworks. Protection which requires that a variety be new rules out many types of seed, therefore excluding peasant and indigenous participation in open source.

For crop populations, the challenge lies in their lack of stability, with their individual variability and subsequent cultivation making it hard to keep track of which seeds have been open sourced. Besides, the many strategies via which crop populations are maintained as heterogenous populations, such as participatory plant breeding, are out of line with ownership or individual authority inherent to both pledge and license arrangements (although attenuated by the copyleft principle).

Most open source initiatives do not include genetically engineered seeds, not because these varieties lack novelty or authority to pledge or license the varieties, but because of strong existing sociotechnical lock-ins with industrial food systems.

Finally, exploring open source approaches for some perennial crops (citrus fruits, coffee, etc.) and so-called minor crops (fonio, moringa, etc.) is an exciting avenue for future research. Indeed, these two crop types have historically been less attractive to the private breeding sector because of long generational cycles of the former and the lack of business opportunities for both.

Functional linkages with the International Treaty on Plant Genetic Resources for Food and Agriculture would nevertheless need to be worked out for all of these biological materials and crop types to ensure consistency across instruments.

Open source for genetic sequence data? The protection of genetic sequence data so far mainly relies on trade secrets and, potentially, patent applications. The open source approach is potentially attractive for those fostering greater openness in data sharing. By contrast to real seeds, genetic sequence data may ultimately be amenable to copyright, thus facilitating the flipping of such protection into copyleft. This would mimic the legal mechanisms regarding free and open-source software, i.e. the initial inspiration for open source for seeds.

However, genetic sequence data mainly applies to the science and technology sector. Collaboration between researchers and farmers is indispensable, but it is still not clear how open source could address the needs of both communities. Researchers are motivated to comply with open access standards while farmers are concerned about appropriation patterns.

The question then arises regarding the extent to which open source, as a protected commons, could offer better protection than open access regimes-this issue requires further assessment. How do these systems differ for the providers of genetic material from which information is extracted? Is open source a viable solution to reconcile openness and appropriation? 


\section{Three open source seed projects in the United States, Germany and East Africa}

\section{The US-based Open Source Seed Initiative}

\section{https://osseeds.org}

The Open Source Seed Initiative (OSSI] is dedicated to maintaining fair and open access to plant genetic resources worldwide in order to ensure the availability of germplasm to farmers, gardeners, breeders, and communities of this and future generations.

OSSI engages in education and outreach that promotes sharing rather than restricting access to plant germplasm, recognizes and supports the work of plant breeders of all kinds, and supports a diversified and decentralized seed industry. The core strategy for achieving these goals is the dissemination and propagation of the OSSI Pledge and of OSSI-Pledged varieties, both of which preserve the rights of farmers, gardeners, and breeders to freely use, save, replant, and improve seed of OSSI-Pledged material.

\section{The Germany-based OpenSourceSeeds organization} www.opensourceseeds.org/en

The German NGO Association for Agriculture and Ecology (AGRECOL, www.agrecol.de/en/agrecol-ev] started work on open-source plant germplasm systems in 2012. An interdisciplinary working group of agricultural scientists, plant breeders and lawyers developed a legally defensible open-source seed license and founded the OpenSourceSeeds service provider. The service provider advises breeders, seed producers and all those interested in seeds, it licenses newly developed cultivars on behalf of breeders, it documents OSS licensed germplasm in a database and stores samples of plant germplasm. In addition, it develops new business models for commons-based plant breeding. OpenSourceSeeds offers its services free of charge and is dependent on donations.

\section{The 'Open Source Seed Systems}

for climate change adaption' Project

implemented in Kenya, Uganda and Tanzania

https://hivos.org/program/open-source-seed-system

The Project, which concerns beans, sorghum, finger millet and forage legumes, is working with smallholder farmers to increase their resilience and improve their adaptive capacity. Its main goal is to increase farmers' access to a much wider range of agricultural biodiversity. The Project will arm them with options to better manage climate risks and biotic stresses such as pests and diseases, while also creating a policy environment for freedom of access and use of these genetic resources by farmers and breeders, which will be vital for future generations to continue adapting.

The Project is supported by the Benefit-Sharing Fund of the International Treaty for Plant Genetic Resources for Food and Agriculture (ITPGRFA, www.fao.org/planttreaty/en], with funding from the European Union and co-funding from the Open Society Foundations [OSF, www.opensocietyfoundations.org] and the CGIAR research program on Climate Change Agriculture and Food Security [CCAFS, https://ccafs.cgiar.org].

The project is implemented by Bioversity International (www.bioversityinternational.org), in partnership with the National Plant Genetic Resources Centre (NPGRC, Tanzania), the National Agricultural Research Organization's Plant Genetic Resources Center (NARO-PGRC, Uganda, www.pgrc.go.ug], the Genetic Resources Research Institute [GeRRI, Kenya, www.kalro.org/Genetic_Resources_Research_Institute], the NGO Hivos (https://hivos.org) and Sustainable Agriculture and Natural Resource Management Africa [SANREM-Africa, http://sanremafrica.org].
The open source seed approach is based on the viral effect and on non-proprietary assets. These two conditions have yet to be tested in the digital genetic information field. For genetic sequence data, it is important to conduct small-scale experiments (consortia, projects) from which lessons can be learned. Moreover, a two-tier approach in which open access is promoted among researchers for existing data whereas bilateral agreements with farmers to respect their rights are developed for new data is another possibility.

Open source for seeds in the Global South? The majority of seed markets in the Global South rely on farmer-managed seed systems, also called 'informal' in contrast to the formal sector. These so-called informal systems are considered open relative to intellectual property rights, but they are under pressure to comply with international regulatory frameworks. The open source approach to seeds is thus relevant for policy makers and smallholder advocacy groups in the Global South, and it could maintain the prevailing openness of seed systems and promote their diversity and flexibility.

The Open Source Seed Systems project for climate change adaption in East Africa is a current example (see box p. 3]. This project recognizes that intellectual property rights is not the only factor responsible for limiting seed system diversity and the exclusion of certain farmers from access to seeds. Marketing rules, certification and registration standards, development aid contracts and free trade agreements are other regulatory frameworks that affect farmers' rights to seed, especially their rights to save, exchange and sell farmsaved seeds. The project promotes different instruments, including:

> community seed banks and the possibility of linking them with national gene banks and researchers,

$>$ participatory evaluation and selection of high performing seeds for climate change adaption and further breeding,

\section{> business cases concerning open source seeds,}

$>$ broad support for women farmers who are key players in safeguarding seed and agrobiodiversity.

It remains to be seen whether this approach could be expanded in other developing countries. There have indeed been qualms about adopting open source for seeds in the Global South. Some perceive it as still linked to seed privatization-an understandable vestige of colonial histories in which 'common heritage' discourses masked regimes in which local seeds were freely appropriated. Moreover, the open source concept can run against the grain in other social and cultural settings-in particular, territorial seed concepts embraced by many indigenous and peasant communities.

\section{The way forward: building the social legitimacy of open source for seeds}

Initiatives that currently promote open source offer insight into local challenges regarding seed access and renewal in both developed and developing countries.

Application of the open source concept to seeds has great potential. It reverses the logic of the intellectual property 
system and expands a renewable stock of open source material outside the exclusive intellectual property realm. With more users, the open source pledge and license will publicly demonstrate the need for alternatives to the current intellectual property system while actively developing the governance and infrastructure for viable protected commons alternatives. Legal defensibility may currently be uncertain, but as open source builds a critical mass of practitioners and supporters, wider social legitimacy can contribute to legal power.

Since open source for seeds is a relatively new concept in both the seed and legal sectors, further experiments are needed-including by expanding in other areas, materially, digitally, geographically, and in terms of the communities most affected by seed rights.
Perspective $\mathrm{n}^{\circ} 49$ is based on an analysis of presentations given at the international workshop Open Source for Seeds (OSS) and Digital Sequence Information which took place at CIRAD on 12 September and 17 October 2017 in Montpellier (France). This workshop was aimed at sharing experience on open source implementation for seeds and promoting discussions on the viability of open source mechanisms in relation to other forms of property in the seed sector, and more broadly in life sciences.

This Perspective is also based on the following three projects in which some of the authors participate (see box p. 3): the US-based Open Source Seed Initiative; the Germany-based OpenSourceSeeds Organization; and the Open Source Seed Systems for climate change adaption Project implemented in East Africa.

The authors and partners have also published several scientific papers on the topics covered in this Perspective:

Coomes O. T., McGuire S., Garine E., Caillon S., McKey D. B., Demeulenaere E., Jarvis D., Aistara G., Barnaud A., Clouvel P., Emperaire L., Louafi S., Martin P., Massol F., Pautasso M., Violon C., Wencelius J., 2015. Farmer seed networks make a limited contribution to agriculture? Four common misconceptions. Food Policy 56: 41-50.

http://dx.doi.org/10.1016/j.foodpol.2015.07.008.

Kloppenburg J., 2014. Re-purposing the master's tools: the open source seed initiative and the struggle for seed sovereignty. The Journal of Peasant Studies 41 (6): $1225-1246$.

https://doi.org/10.1080/03066150.2013.875897.
Labeyrie V., Thomas M., Muthamia Z. K., Leclerc C., 2016. Seed exchange networks, ethnicity, and sorghum diversity. PNAS 113 (1): 98-103. http://dx.doi.org/10.1073/pnas.1513238112.

Louafi S., Welch E. W., 2014. Disentangling the debate on open access for meeting global challenges in life science. In Innovation for sustainable development. Grosclaude J.-Y., Pachauri R. K., Tubiana L. (Eds). TERI Press, New Delhi, p. 145-159. ISBN 978-8179935569. http://agritrop.cirad.fr/573370.

Louafi S., Bazile D., Noyer J.-L., 2013. Conserving and cultivating agricultural genetic diversity: transcending established divides. In Cultivating biodiversity to transform agriculture. Hainzelin É. [Eds). Springer, Dordrecht, p. 181-230. ISBN 978-94-007-7983-9. http://dx.doi.org/10.1007/978-94-007-7984-6_6.

Luby C. H., Kloppenburg J., Michaels T. E., Goldman I. L., 2015. Enhancing freedom to operate for plant breeders and farmers through open source plant breeding. Crop Science 55 (6): 2 481-2 488. https://doi.org/10.2135/cropsci2014.10.0708.

Montenegro de Wit M., 2017. Beating the Bounds: How Does 'Open Source' Become a Commons for Seed? The Journal of Peasant Studies. https://doi.org/10.1080/03066150.2017.1383395.

Montenegro de Wit M., 2016. Are We Losing Diversity? Navigating Ecological, Political, and Epistemic Dimensions of Agrobiodiversity Conservation. Agriculture and Human Values 33 (3): 625-640. https://doi.org/10.1007/s10460-015-9642-7.

\section{A few words about...}

Sélim Louafı is a social scientist at CIRAD (France) in the UMR AGAP (Genetic Improvement and Adaptation of Mediterranean and Tropical Plants joint research unit, https://umr-agap.cirad.fr/en]. He works on science and global policy interactions in the field of agricultural biodiversity.

selim.louafi@cirad.fr

Ida Westphal is a German lawyer with a specialization in agricultura and environmental law. As a Mercator Fellow on International Affairs (www.stiftung-mercator.de/en), she is currently working on alternative licensing models for seeds.

Maywa Montenegro is a social scientist specializing in political ecology and Science-Technology-Society approaches to seed epistemologies, policies and politics. She has a PhD in Environmental Science, Policy and Management from the University of California, Berkeley (https://ourenvironment.berkeley. edu), and is currently a UC President's Postdoctoral Fellow at the University of California, Davis (www.ucdavis.edu).

\section{Some links}

Bollier D., 2014. Think like a commoner: A short introduction to the life of the commons. New Society Publishers, Gabriola Island, BC, $192 \mathrm{p}$ ISBN 9780865717688. http://thinklikeacommoner.com.

Consultative Group for International Agricultural Research (CGIAR) www.cgiar.org.

Commons Transition Platform. http://commonstransition.org

International Union for the Protection of New Varieties of Plants (UPOV). www.upov.int.

This article is provi-
ded under the terms of
the Creative Commons
4.0: Attribution 4.0
Iicense CC-BY
International https://creativecommons.org/
licenses/by/4.0
Manzella D., Otieno G., Steigerwald S. Kloppenburg Genetic Sequence Data: Practical experience and https://doi.org/1019182/agritrop/00063.
Daniele Manzella is a legal and policy expert at the Secretariat of the International Treaty on Plant Genetic Resources for Food and Agriculture at FAO, Rome, Italy (ITPGRFA, FAO, www.fao.org/in-action/right-to-foodglobal/global-level/itpgrfa/en]

Gloria Otieno is a Genetic Resources and Food Security Policy Specialist at Bioversity International, Uganda (https://www.bioversityinternational.org). She holds a PhD in Development Economics from the International Institute of Social Studies of the Erasmus Universiteit Rotterdam, Netherlands [EUR, www.eur.nl)

Sophie Steigerwald is a German Master's student in Organic Agriculture. She is interested in plant breeding and seed policy and is working for the OpenSourceSeeds organization (www.opensourceseeds.org/en).

Jack Kloppenburg is a Professor Emeritus in the Department of Community and Environmental Sociology at the University of Wisconsin-Milwaukee US (UWM, http://uwm.edu). He is a founder of the Open Source Seed Initiative [OSSI, http://osseeds.org].

\section{Publication Director: Michel Eddi, CIRAD President Managing Director Editors: Patrick Caron, Office of the Director General in charge of Research and Strategy Cécile Fovet-Rabot AGRICULTURAL RESEARCH FOR DEVELOPMENT 42 , rue Scheffer 75116 Paris • France www.cirad.fr \\ Editing: David Manley \\ Graphic design: Delphine Lavastre-Guard \\ Communication Service \\ Distribution: Christiane Jacquet, Communication Service}

www.cirad.fr/en/publications-ressources/edition/perspective-policy-brief perspactive ISSN-L 2275-9190 - Email: perspective@cirad.fr

\section{a. M U S E}

MONTPELLER UNIVERSTÉ DEXCELENCE http://muse.edu.umontpellier.fr 